\title{
Environmental Approach to Managing Defective Products and Waste in the Household Appliances Industry
}

\author{
Marta Starostka-Patyk* \\ Częstochowa University of Technology, Faculty of Management, Częstochowa, Poland
}

Received: 4 May 2018

Accepted: 16 July 2018

\begin{abstract}
The paper describes solutions that might have a huge environmental impact on the management of defective products and waste. It presents briefly the concepts of sustainable development, ecological design, closing material loops and the treatment options used to recover the value from defective products and waste, turning them into secondary raw materials. The Polish household appliances (HA) industry case is presented, as it is one of the biggest industries in Poland as well as dynamically developing. The research points out the options to manage HA defective products and waste, highlights the practices at this field of HA manufacturing enterprises, and creates the directions to be followed by the companies to become more environmentally focused, especially by designing their products with regard to ecological issues, following product life cycles, recovering the value from them, reusing materials in closed loops and finally by these elements generating less defective products and waste to not harm the natural environment.
\end{abstract}

Keywords: environment; management; household appliances (HA) industry; defective products; waste; sustainable development; ecological design; life cycle; closed material loop; Poland

\section{Introduction}

Currently one of the most important challenges that must be faced by enterprises and various economies is to implement a sustainable development concept. It strives for an integrated economic, social, environmental, spatial as well as institutional and political order [1]. In its basic, statutory definition, it is found that sustainable development is socio-economic development that integrates political, economic and social actions, with

*e-mail: marta.starostka-patyk@wz.pcz.pl perseverance of natural balance and stability of basic natural processes, in order to provide for a possibility to fulfill basic needs of particular communities or citizens, of both contemporary and future generations [2]. The enterprises undertake implementation of the sustainable development concept, being aware that they exert intensive influence on the natural environment by utilizing natural resources, emitting pollution or generating waste, and the expectations towards their operations are focused on the trends toward limited use of materials and resources and improvement of contribution to social life [3].

A special case in the sphere of sustainable development is posed by manufacturing enterprises, 
which base their key operational parameters on the products, materials and energetic resources, adopting in the manufacturing process manners of storage and distribution, post-sales services, possibilities for final disposal of products, and their reuse by different treatment options [4]. All of those processes can be significantly reflected in the potential for seeking the possibilities for production dematerialization, reduction of its energy consumption, introduction of a low-emission and waste-free manufacturing system, limitation of dysfunctions of products in their life cycles, generation of material and power feedback and their use to supply some new cycles [5]. These actions combine economic and ecological benefits, and indirectly some social advantages, thus they pose a determinant for a specific direction for the manufacturing enterprises management [6].

Due to the adaptation of the production enterprises to the requirements of sustainable development, many of them adapt the directions of their business development to areas related to the ecological design of their products, including design for reuse to reduce negative impact on the natural environment (Fig. 1).

In the global economy, a trend is observed related to the use of an ecological approach in production processes. This reflects the need to implement the priorities of sustainable development, including mainly the priority of protecting the natural environment from harmful substances and activities [7]. Bearing in mind the limited amount of natural resources and the need to reduce the environmental burden of production residues (waste and defective products), more attention is paid to product design in an ecological way [8].

Ecological design involves the use of appropriate, ecological materials and components as well as waste-

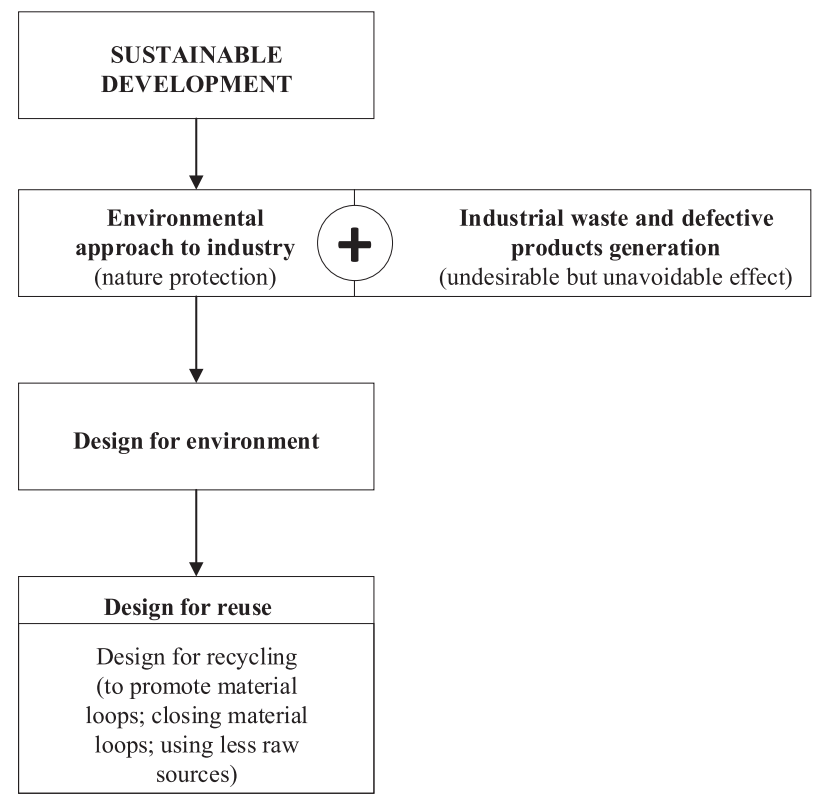

Fig. 1. Directions of development of enterprises taking into account the environmental priority of sustainable development. free production methods [9]. Designing ecological products is a comprehensive process, where not only the products are ecological, but also the method of their production [10]. This complexity means that the ecological design of products fits into modern production trends.

The first mention of the integration of environmental elements with the development of products appeared in literature in the 1970s. Then the main goal of such activities was to reduce the amount of solid waste generated by industry and society, and the fact that they irrevocably lost their value by ending up in landfills. Attempts to reuse waste were associated with the development of a circulation-oriented approach to materials (closed material loops). Products and services were considered ecological when their production, use, and recovery at the end stage of product life, and recycling or other development required a minimum amount of materials and energy, and also generated the least amount of waste (solid, liquid and gas) [11].

Ecodesign includes the material and energy balance for a better assessment of the resources necessary for the development of a product and for evaluating the impact on various ecosystems [12].

In the literature there are often other terms used for ecodesign, such as ecological design, sustainable design, and responsible design, but all of them aim to design products respecting the principles of sustainable development and natural environmental protection.

Ecodesign is seen as an approach that takes into account environmental impacts in product design and development. These impacts refer to the whole product life cycle, from raw material supply to production, distribution, and use [13].

The ecodesign concept includes environmental criteria concerning the consumption of raw materials, water and energy, the emission of pollutants into water and air, as well as waste production [14]. It is a major aspect of the prevention and reduction at the source of environmental impacts. However, ecodesign allows for the innovations and creativity of industrialists as it states as a new opportunity for differentation and for a future competitiveness factor [15]. Designers can choose and combine solutions because it is a multicriteria approach.

The general idea of ecodesign is to avoid or minimize the impacts of product life cycle on natural environment, human health, and natural resources [16]. The main categories of these impacts are presented in Fig. 2.

Ecological product design is mainly based on the fact that companies that use this type of processes gain not only to the ecological selection of raw materials and ecological production, but also to the product which after use by the end user is not harmful to the environment, and at the same time would be suitable to recover raw materials that can be reused in the production [18].

Modern enterprises, while manufacturing goods, think forward to be able to forecast what will happen with their products when they will finish their life cycle 


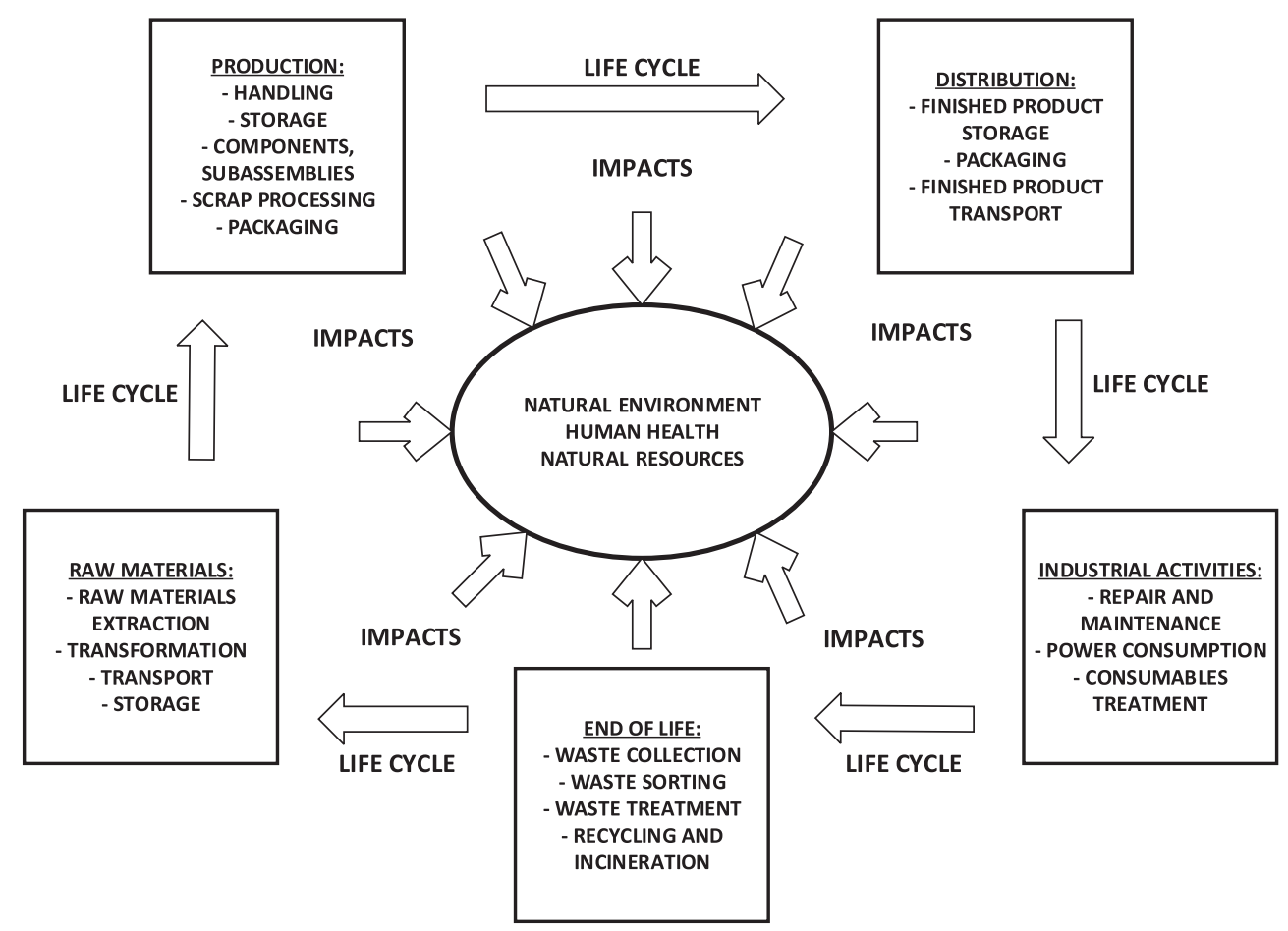

Fig. 2. Product life cycle and impact on natural environment, human health and natural resources caused by its main stages [own elaboration based on 17].

[19]. Such an approach is also useful to create the closed material loops. By usage of secondary raw materials in production, it is possible to seek to close material loops [20]. Regarding the loop subject, it is possible to separate two characteristic structures, an open and a closed loop, which result from the course of actions in the sphere of implementation of the materials circulation concept.

An open loop is when the backward flows are directly addressed to the units that process the returns and waste (e.g. recycling organizations) or to landfills [21].

The closed loop emerges when the backward flows address their content to the spots that carry out the value recovery processes, and afterwards this content having a form of recovered materials is directed to the starting point of the enterprise, thus supplying the forward flows with secondary raw materials [22]. The recovered value comes back to the same enterprise (or industry) in a closed loop (Fig. 3).

The closed loop is characterized with recirculation of content of the backward flows. These flows lead to the units, where the process reinstating the value of products or waste is carried out, so they can supple the forward flows from the starting point of the enterprise in whole, partial, or in a form of secondary raw materials [24]. The backward flows in a closed loop are subjected to strict quality monitoring, and as based on the results of that control there are certain decision made on final disposal and use of the flow contents [25].

From the environmental perspective, and also the economic one, the closed loops of materials flows in enterprises or whole industries are more advantageous as they bring measurable ecological advantages in a form of being environmentally-friendly and limiting the emissions for the enterprises and participants of their business surroundings, in a form of added value that results from the use of secondary instead of primary raw materials [26]. At the same time, the closed loops are certainly more difficult in implementation and more complex in management, therefore their implementation causes plenty of problems in numerous enterprises, and in some of them they are not implemented at all [27]. Here, an additional difficulty is posed by the technical and technological barrier, as often the investment in modern possibilities of value recovery outgrows the possibilities of the enterprise.

\section{Experimental}

\section{Research Methodology: the HA Industry as a Source of Defective Products (and Waste)}

\section{HA Industry Characteristics}

The HA industry is one of the most dynamically developing production sectors in Poland, taking second place (after Italy) in Europe. In fact, for several years now it has been characterized by the highest production volume of household appliances, and despite the downward trend recorded for their exports this industry is increasing its production every year. 


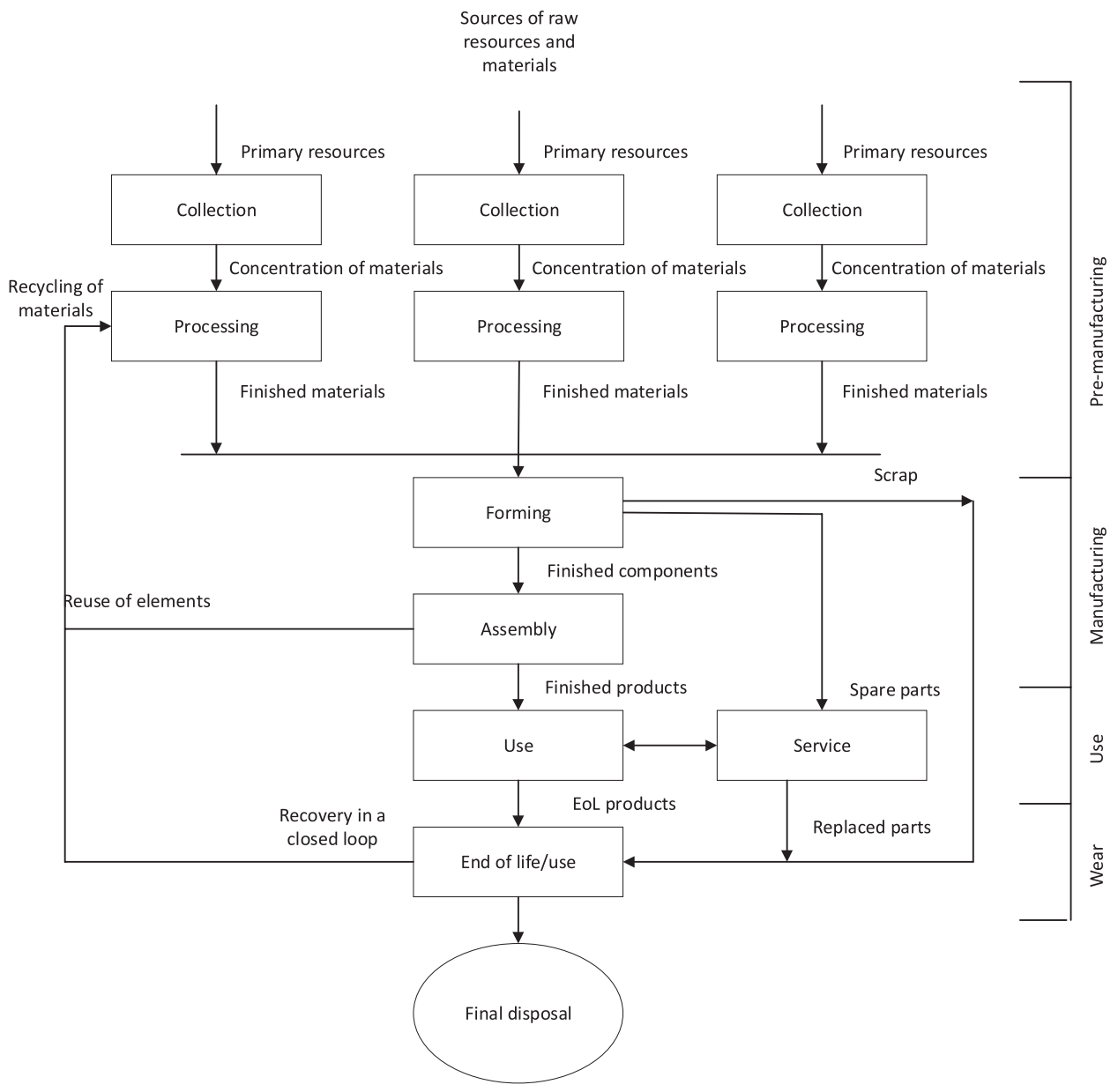

Fig. 3. Closed loop of materials [own elaboration based on 23].

In 2016, the size of the domestic HA market was estimated at nearly PLN 9.5 billion, and in the sector of HA production there were about 25,000 employees in 30 factories located regionally in 3 central voivodships.

Analyzing CECED data [28], which allows to compare the production of HA in 2016 and 2017 (Table 1), shows that there is quite a dynamic growth, especially in the case of manufacturing small HA (13\%). Production of large HA in 2017 increased by $2 \%$, and small HA by $13 \%$ compared to 2016 . Generally, the production of HA in 2017 is higher than in the previous year by $4 \%$, which undoubtedly indicates a development trend of the HA industry in Poland.

At the same time, the sales and disposal of HA is characterized by dynamics. In 2016, 5.5 million pieces of large HA and 10 million small HA were sold in Poland. In addition, exports of Polish HA accounted for $24 \%$ in the German market, $12 \%$ in France and the United Kingdom, 9\% in Italy, 5\% in Spain and Sweden, and $4 \%$ in Russia [29].

This means that due to the large volumes of both production and sales of HA, this industry is introducing large quantities of HA to the market. For this reason, it belongs to the sector with a high potential for the generation of defective products ${ }^{1}$, as well as used products, in the form of waste that must be removed from the market according to the assumptions of environmental protection.

\section{Research Sample}

As part of the project implementation (details in acknowledgment), in the first quarter of 2014 a survey was conducted in Polish manufacturing enterprises from sectors with high potential for defective products, mainly from the automotive sector, HA industry, electronic and computer equipment, toy and clothing production, etc.

The questionnaire contained 20 questions and the research sample covered 302 production companies located in Poland. The sample was designated on the basis of statistical calculations and is a representative sample, therefore the survey results reflect the situation of all Polish manufacturing enterprises.

A defective product is each product that is not waste, which however does not meet the quality and/or functional requirements against which it was manufactured, at various stages of its life cycle [30]. 
Table 1. Production of HA in Poland in 2016 and 2017 [own elaboration based on 28].

\begin{tabular}{|c|c|c|c|}
\hline Products in thous. pcs & $\mathbf{2 0 1 6}$ & $\mathbf{2 0 1 7}$ & $\begin{array}{c}\mathbf{2 0 1 7} \text { vs. } \\
\mathbf{2 0 1 6}\end{array}$ \\
\hline Refrigerators and freezers & 3157 & 3222 & $2 \%$ \\
\hline Dishwashers & 4693 & 4593 & $-2 \%$ \\
\hline Washing machines & 6458 & 6711 & $4 \%$ \\
\hline Dryers & 2559 & 2686 & $5 \%$ \\
\hline Cooking equipment & 5131 & 5262 & $3 \%$ \\
\hline Total Large HA & $\mathbf{2 1 ~ 9 9 8}$ & $\mathbf{2 2 ~ 4 7 4}$ & $\mathbf{2 \%}$ \\
\hline Vacuum cleaners & 719 & 1194 & $66 \%$ \\
\hline Blenders, food mixers & 3470 & 2615 & $-25 \%$ \\
\hline Kettles & 1196 & 1037 & $-13 \%$ \\
\hline Total Small HA & $\mathbf{4 2 8 7}$ & $\mathbf{4 ~ 8 4 6}$ & $\mathbf{1 3 \%}$ \\
\hline Total HA & $\mathbf{2 6 ~ 2 8 5}$ & $\mathbf{2 7 ~ 3 2 0}$ & $\mathbf{4 \%}$ \\
\hline
\end{tabular}

The research included issues related to defective products and the manner of their management in the surveyed enterprises. The survey had a quantitative character and was carried out in the form of a telephone interview (CATI) by an external company specializing in this type of research.

The respondents of the survey were representatives of enterprises holding managerial positions at the level of the whole enterprise and persons designated by them as responsible for accepting returns and developing the company's strategy and policy in this regard.

In order to characterize the Polish HA industry in the context of managing defective products and the resulting needs related to ecological design and closed material loop, this article presents the selected part of the survey results. Additionally, in order to strengthen the survey results, they are supported by information obtained through an additional examination in the form of direct interviews. These interviews were conducted in 2014 and 2015 at selected manufacturing companies. In the case of the HA industry, 4 interviews have been implemented.

\section{Results and Discussion}

\section{Defective Products (and Waste) Management in HA Industry}

\section{General Overview of Polish HA Industry}

For the purposes of the context of this article, the results of the study identified a group of enterprises that are producers of $\mathrm{HA}$, that is 27.5 and 27.9 according to the Polish Classification of Activities. On the basis of the respondents' answers from this group, it is possible to generalize inferences about the management of defective products in the entire industry. It is also possible to apply for opportunities to shape this industry market in terms of eco-design aiming at the reuse of products or parts of them.

Polish producers of HA categorizing defective products indicate the presence of damaged products $(40 \%)$, product components $(40 \%)$, waste and byproducts $(40 \%)$, and packaging $(40 \%)$. Other categories of defective products, i.e., outdated products, seasonal products, unsold in retail, or withdrawn from sale and erroneously considered as defective, appear in the HA industry at a lower intensity, i.e., below $10 \%$.

Defective products from the HA industry are returned to the producer most often within a period from one week to one month from the moment of their distribution ( $80 \%$ of respondents) or from one month to three months $(20 \%)$. When defective products are already in the possession of the producer, their qualitative status in relation to the primary condition by respondents is defined as satisfactory $(20 \%)$, good $(20 \%)$ and very good $(60 \%)$. The processing cycle of acquired defective products usually lasts from 1 to 2 days $(40 \%)$, from 2 days to a week (20\%), from one week to two weeks $(20 \%)$, and from 2 weeks to a month $(20 \%)$.

Polish manufacturers of HA recognize their policy of accepting returned defective products as very liberal (60\%). As part of managing defective products, enterprises accept their returns themselves (60\%), outsource to third parties (20\%), independently renew them through cleaning, repair, etc. (20\%), use recovered components or raw materials for production (40\%), organize the sale $(20 \%)$ and carry out recycling and scrapping (40\%). Recycling is also outsourced to third parties $(20 \%)$.

$80 \%$ of the surveyed producers of HA admitted that returned defective products reduce the profitability of their company. At the same time, these enterprises decide to accept returned defective products because they perceive this action as important in building a competitive position through: product quality $(100 \%)$, price and speed of delivery $(80 \%$ each), and cost reduction, return policy and product differentiation $(60 \%$ each). According to the majority of respondents $(80 \%)$, the management of defective products positively affects the implementation of the company's goals.

Polish HA manufacturers point out that the most important barriers to effective management of defective products are the company policy (40\%) and financial resources $(40 \%)$, followed by competitiveness $(20 \%)$, legal conditions (20\%), lack of management attention $(20 \%)$, and lack of staff competence (20\%). Organizational solutions and the importance of this issue are not perceived as barriers.

\section{Management of Defective Products - Treatment Options}

Bearing in mind the high volume of HA production 
in Poland, the natural consequence is the appearance of defective products in enterprises of this industry. According to data from the survey, HA manufacturers estimate the level of returned defective products in the range of 2 to $10 \%$ of total production. Although this percentage is small, given that in 2017 the production of large HA amounted to almost 22.5 million units and the small HA almost 5 million units, 2 to $10 \%$ of total production is a quite large number of defective HA products. This is the basis for the conclusion that taking action related to the appropriate management of defective products by using the treatment options is justified, as well as it is necessary to develop the ecodesign procedures to enable the reuse of materials for new goods production and to protect the natural environment.

Analyzing the flow of returned defective products in enterprises, at the end, they proceed to the final disposal process. It is a complicated and comprehensive process as there are various options for recovering value from the returns. The returns in the final disposal process first undergo a thorough inspection. Its purpose is to ensure accuracy of undertaken decisions regarding their further direction to an appropriate final disposal option. Within the previous controlling and sorting process, the decision about the returns' final disposal option is also undertaken, but it is not a final decision. Some additional information about the condition of the returns may appear in the final disposal process, so the final decision is the one regarding the final disposal option made in this process (Fig. 4).

Ten treatment options can be identified in the defective products' final disposal process: repackage, repair, disassembly, reconfiguration, remanufacturing, upgrade/modernization, recycling, donation to charitable purposes, sales on another market, or delivery to a landfill [31]. Each option (except delivery to a landfill) ends with a repeated inspection of the products or material collected within the final disposal process. It is necessary for some defective products, after implementation of one final disposal option, may require another option to optimize the value recovery. Hence, the final disposal process is characterized with recirculation of secondary material flows on this stage.

- Repackage is the simplest option for final disposal of returns. The product is repackaged into the same packaging, or if it causes any reservations to the quality, then it is packed into new packaging.

- Repair consists of the reinstatement of the damaged or non-operational products into service.

- Disassembly consists of obtaining modules or components from the products and reusing them.

- Reconfiguration consists of the implementation of minor modifications in the product's configuration to prepare it for reuse in conditions similar to the original ones. It is mainly related to switching

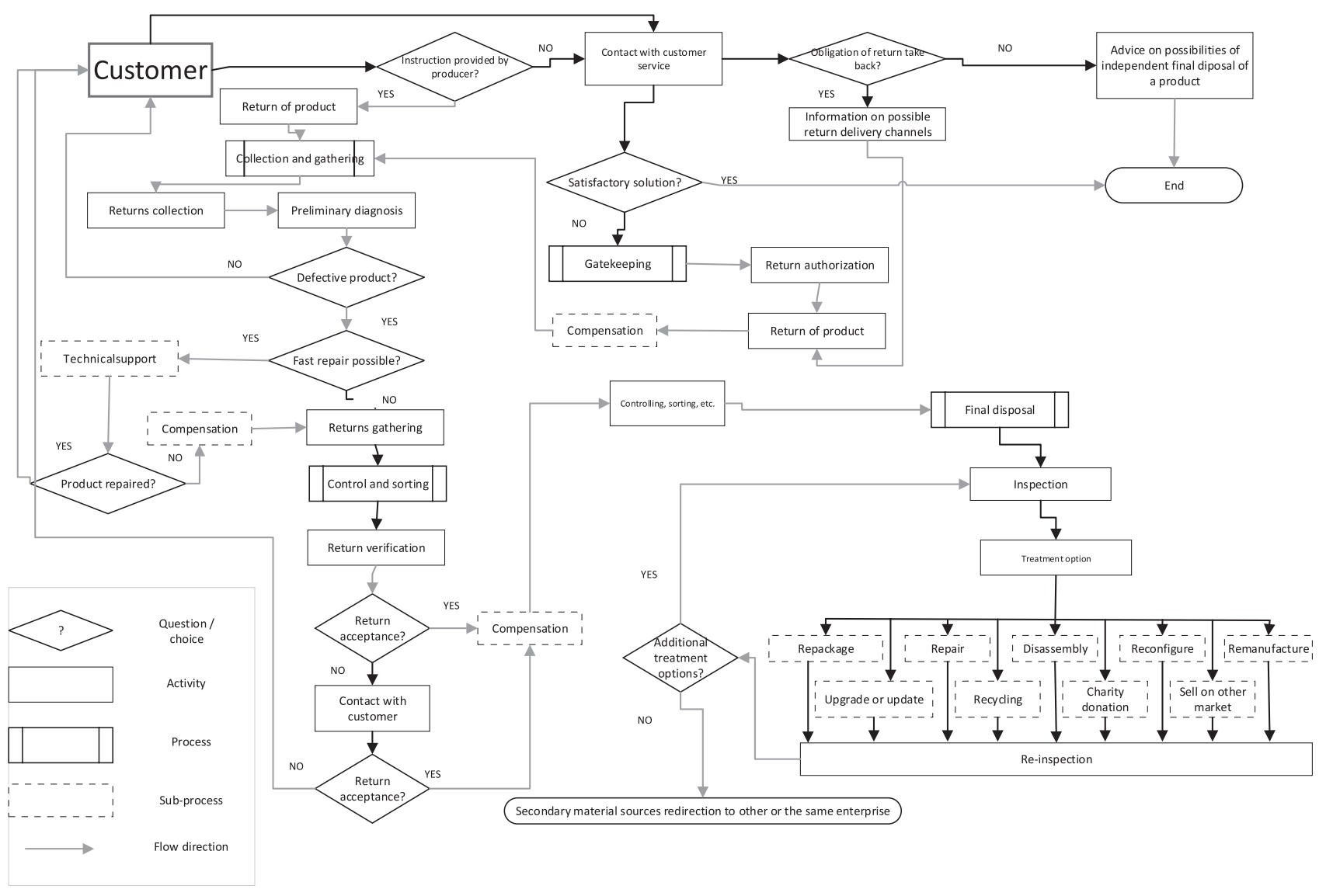

Fig. 4. Defective products management model in the exemplify enterprise manufacturing household appliances (HA). 
Table 2. Values of statistics $\chi 2$ and the Youle's correlation coefficient $\varphi$ for emergence intensity of defective products in Polish household appliances enterprises and the accompanying variables category from the group of treatment options in the scope of the defective products management.

\begin{tabular}{|c|c|c|c|}
\hline Variables $\quad$ Indicator & & $\chi^{2}$ & $\varphi$ \\
\hline \multicolumn{4}{|c|}{ Damaged products } \\
\hline Reconfigure & (1) & $5.237 *$ & 0.284 \\
\hline Repackage & (2) & $14.990 \%$ & 0.480 \\
\hline Remanufacture & (3) & $12.073 *$ & 0.431 \\
\hline Repair & $(4)$ & $11.296 *$ & 0.417 \\
\hline Sell on other market & $(5)$ & $12.994 \%$ & 0.447 \\
\hline Disassembly & $(6)$ & $5.602 *$ & 0.294 \\
\hline \multicolumn{4}{|c|}{ Seasonal products } \\
\hline Repackage & $(7)$ & $7.857 *$ & 0.348 \\
\hline Upgrade or update & $(8)$ & $9.470 *$ & 0.382 \\
\hline Sell on other market & $(9)$ & $5.677 *$ & 0.296 \\
\hline Disassembly & $(10)$ & $5.602 *$ & 0.294 \\
\hline \multicolumn{4}{|c|}{ Products unsold in retail } \\
\hline Charity donation & (11) & $9.470 *$ & 0.382 \\
\hline Repackage & (12) & $7.857 *$ & 0.348 \\
\hline Upgrade or update & (13) & $9.470 *$ & 0.382 \\
\hline Sell on other market & (14) & $5.677 *$ & 0.296 \\
\hline \multicolumn{4}{|c|}{ Products erroneously taken as defective } \\
\hline Repackage & $(15)$ & $5.631 *$ & 0.294 \\
\hline \multicolumn{4}{|c|}{ Products components } \\
\hline Upgrade or update & (16) & $5.721 *$ & 0.297 \\
\hline Repair & (17) & 4.038* & 0.249 \\
\hline Sell on other market & $(18)$ & $7.262 *$ & 0.334 \\
\hline Recycling & (19) & $5.346 *$ & 0.287 \\
\hline \multicolumn{4}{|c|}{ Waste- and by-products } \\
\hline Remanufacture & $(20)$ & $3.616 *$ & 0.236 \\
\hline \multicolumn{4}{|l|}{ Packaging } \\
\hline Recycling & $(21)$ & $3.438 *$ & 0.230 \\
\hline
\end{tabular}

the language of the operating manual so the product can be sold in another country, changing of the label and replacement of some parts to adjust the products for requirements of consumers in a different state.

- Remanufacturing is a process similar to repair as it consists of the reinstatement of modules, components or whole products to their original conditions, which may then be reused.
Remanufacturing is different from repair as it allows regular modification on a greater number of used or damaged products, using a more specialized and deeper process.

- Upgrade/modernization is intended to bring older types of the products to the latest version. This is related to adding new functionalities to products by replacing parts, components, or modules. This process is very similar to the remanufacturing process, but it differs with the purpose - the remanufacturing is intended to prolong the product's life cycle, while this process is intended to improve the functionality or appearance of the product.

- Recycling is based on extraction of raw materials from the returned defective products. Hence, the necessity to use primary materials for production is reduced as they can be replaced with some recycled goods.

- Donation for charitable purposes consists of handing the products to a nonprofit organization. Generally, the only advantage for enterprises here is improvement of image.

- Sales on another market consists of directing the correctly functioning products to a different, alternative market, characterized with lower customer expectations regarding the fact that the returned defective products do not correspond to the requirements of the current market or fail to meet the quality criteria for this market.

- Delivery to a landfill is actually related only to the parts of products that show no value, and thus they become waste. This option also means that the waste is allocated for incineration. The waste must be free from hazardous materials before implementing the process, which is the least desired option because despite the possibility of generating energy, it brings no advantages for the enterprises and harms the natural environment with pollution.

Each treatment option of the defective products, apart from delivery to a landfill - an adverse but sometimes necessary action - leads to recovery of the value included in these products. Thanks to the final disposal options, the recovered secondary value is in a form of whole products, parts and components, or raw materials that can supply with the secondary materials the enterprise (or other enterprise) again.

The researched household appliance enterprises adopt all the above options (except the last one, delivery to the landfill, which is caused not only by legal and environmental regulations but also the products specificity itself), which as returns allow total recovery of value without being transformed into waste. The household appliances enterprises adopt the options at the following rates per year: repackage about $5 \%$ of returns, upgrade or update about $15 \%$, repair about $55 \%$, recycling about $5 \%$, disassembly about $3 \%$, reconfiguration about $5 \%$, remanufacturing about $5 \%$, sales on a different market about $5 \%$ and donation to charitable purposes about $2 \%$. 


\section{Analysis of Interdependences between Treatment Options and Defective HA Products}

While researching Polish HA enterprises, the interdependence analysis was implemented with statistics $\chi^{2}$ and Youle's correlation coefficient $\varphi$. The analysis covered interdependencies between emergence intensity of defective products in the form of returns in the examined HA enterprises, i.e.: damaged products, outdated products, seasonal products, products unsold in retail, products withdrawn from sales, products erroneously taken as defective, product components, waste and by-products, packaging [32], and the accompanying variables category from the group of treatment options in the scope of the defective products management. Examination of these correlations proved that significant statistical interdependencies are present in the case of emergence intensity of the defective products and particular variables from the group of treatment options, i.e., repackage, upgrade or update, repair, recycling, disassembly, charity donation, reconfigure, sell on other market, remanufacture, as related to determination of actions in the scope of the HA defective products management in Polish enterprises. Results of this analysis are presented in Table 2.

Moreover, in the case of emergence intensity of outdated and withdrawn products, no statistically significant correlations with any of the researched variables category were confirmed, so they are not presented in the table.

The interdependencies presented in Table 2 confirm the occurrence of correlations between emergence intensity of some defective products in HA enterprises and independence of some treatment options undertaken in the scope of the defective products management by the enterprises.

There is a statistically significant interdependence (1) between reconfiguration of returns and the damaged products' emergence intensity in HA enterprises. Enterprises that record damaged products significantly more often perform treatment options related to reconfiguration. A similar situation refers to options that consist of: repackaging (2), remanufacture (3), repair (4), sell on other market (5), and disassembly (6).

When it comes to HA defective products management, the occurrence of seasonal products is correlated with the following treatment options undertaken by the enterprises: repackage (7), upgrade or update (8), sell on other market (9), and disassembly (10). In this case, these interdependencies are clearly in the majority and they become stronger along the increase in emergence of seasonal products in the HA enterprises.

The emergence intensity of the products unsold in retail is correlated with frequency of treatment options carried out by the HA enterprises, covering: charity donation (11), repackage (12), upgrade or update (13), and sell on other market (14). These interdependencies are for the majority clear in this case, and they become more intensive along with the increase in emergence intensity of the products unsold in retail in the HA enterprises.

The enterprises that employ production from recovered components or raw materials apart from traditional manufacturing processes more often notice the significance of emergence of products erroneously taken as defective in the reverse flows (15).

The emergence intensity of the returned products' components is correlated with the enterprises' undertaking treatment options related to defective products management in the form of upgrade or update (16), repair (17), sell on other market (18), and recycling (19). Also, these interdependencies are clear and they intensify along with growing emergence intensity of the products components among the returns of defective products in the HA enterprises.

When it comes to treatment options undertaken by HA enterprises in relation to defective products management, the emergence intensity of waste and byproducts is correlated with remanufacture (20), as the enterprises that remanufacture their products are rarer at generating waste and by-products qualified to the category of defective product returns.

While emergence intensity of packaging in the HA enterprises is correlated with implementation of recycling by those enterprises (21), allowing them to recover at least a part of the value included in this category of defective products.

The confirmed correlations suggest that even though Polish HA enterprises do not have direct impact on the emergence intensity of the defective product returns, they still indirectly, through treatment options related to the defective products management, influence this intensity. This is first related to situations when the enterprises collect the defective product returns on their own, and see their potential to generate environmental and economic benefits by adopting them into management operations and, while treated by different options, generate secondary raw materials.

\section{Management of Waste HA Products}

However, it must to be noticed that the above analysis is made for defective products returned by the final customer to the HA enterprises that have been researched. In the HA industry there is also a challenge related to the collection of used (waste) appliances. According to the data regarding the operation of the waste electrical and electronic equipment management system in 2016 [33], $214731043.11 \mathrm{~kg}$ of HA products were collected from households, which accounts for $92.29 \%$ of the total weight of collected waste equipment. From other sources than households $17,92239.15 \mathrm{~kg}$, which is $7.71 \%$ of the weight of the above equipment. The largest amount of used equipment was collected in the group of large-size household appliances (LHA), 115737543.62 kg, 
Table 3. Recovery, preparation for reuse and recycling of waste HA products, as well as recovery levels and preparation for reuse and recycling of waste HA products in 2016 [own elaboration based on 33].

\begin{tabular}{|c|c|c|c|c|c|}
\hline & $\begin{array}{c}\text { Mass of waste generated from } \\
\text { waste household appliances } \\
\text { subject to recovery processes } \\
\text { (including preparation for } \\
\text { reuse and recycling) }\end{array}$ & $\begin{array}{c}\text { The reached level } \\
\text { of recovery of } \\
\text { waste household } \\
\text { appliances }\end{array}$ & $\begin{array}{c}\text { Mass of waste } \\
\text { generated from } \\
\text { recycled waste } \\
\text { household } \\
\text { appliances }\end{array}$ & $\begin{array}{c}\text { Mass of waste } \\
\text { household } \\
\text { appliances } \\
\text { prepared } \\
\text { for reuse }\end{array}$ & $\begin{array}{c}\text { The reached level } \\
\text { of waste household } \\
\text { appliances } \\
\text { prepared for reuse } \\
\text { and recycling }\end{array}$ \\
\cline { 2 - 6 } & $\mathrm{kg}$ & $\%$ & $\mathrm{~kg}$ & $\mathrm{~kg}$ & $\%$ \\
\hline $\begin{array}{c}\text { Large-sized } \\
\text { household } \\
\text { appliances (LHA) }\end{array}$ & 97615854,03 & 86,58 & 97187404,67 & 78086,00 & 86,27 \\
\hline $\begin{array}{c}\text { Small-sized } \\
\text { household } \\
\text { appliances (SHA) }\end{array}$ & 18228657,10 & 88,59 & 18127699,30 & 74308,00 & 88,46 \\
\hline
\end{tabular}

which is $49.74 \%$ of the weight of collected waste equipment. A significant share in the weight of collected used equipment is also the equipment from the group of small-sized household appliances (SHA) $23987277.13 \mathrm{~kg}$, which is $10.31 \%$ of the total weight. A part of those HA waste products were subjected to recovery processes such as recycling or other treatment options for materials reuse. Detailed data is presented in Table 3.

The data presented in the table clearly indicates positive tendencies related to recovery, recycling and reuse of waste from the HA industry. High percentage indicators mean that waste of HA products represents value that is possible to be extracted. According to the reports on HA industry activities, these tendencies and indicators should be even higher during the next few years.

\section{Conclusions}

The current economic realities are forcing enterprises in today's actions to achieve sustainability, particularly in production [34]. This is a necessity due to the increasing attention paid to environmental protection and the related environmental management [35]. Manufacturing companies in this respect have to take into account many different aspects and focus not only on the production of products but also on the management of their residues, i.e., defective products and waste [36]. HA industry states here as the one of the most important because its products have a lot of impact on the natural environment, as well as quite large volumes of residue that are necessary to be managed according to the strict Polish and European Union law in this regard.

Research results present the HA industry as using different treatment options to manage residues, which makes it possible to recover their value and reuse them. Observing the life cycle of HA products, creating new HA products according to the eco-design guidelines, and usage of secondary raw materials in production are just some of the environmental solutions for developing sustainability of this industry.

However, it is necessary to highlight that HA products contain a lot of parts, components and raw materials, which are stating the potential for secondary raw materials. For such a perspective the key objective for now and for the nearest future is to use this advantage to improve the closed material loop in the HA industry and try to create a circular economy.

It might be useful to create incentives to:

- Better manage the defective products and waste to recover more valuable resources.

- Develop the new requirements regarding eco-design and mark products to simplify disassembly processes reuse and recycling.

- Create the systems of defective products and waste collection supporting recovery options.

- Improve the conditions of usage in the hierarchy of defective products and waste management.

- Create broader utilization of economic instruments to ensure consistency of defective products and waste management procedures.

- Support the certification and increase the safety of technologies and equipment for material recovery processes.

- Support development of clear quality requirements for secondary raw materials.

- Resolute separation of defective products and secondary raw materials from waste.

- Support facilitation of secondary raw materials for international circulation.

- Create good and environmentally friendly images of products manufactured with the use of secondary raw materials.

- Support the development of secondary raw materials markets.

- Follow not only the main product life cycle but also the life cycle of its components parts and materials.

- Enhance cooperation between the industry and governments.

- Promote the closed material loops.

Therefore, by comparing the research results on current activities in the area of defective products 
and waste management in HA enterprises while striving for continuous economic growth and market development of the HA industry, it is necessary for the enterprises to adopt to such a dynamic environment and their openness to change. Companies must still look for appropriate strategies and work on solutions that allow them to easily accept the requirements of sustainable development and natural environment protection. There are also required skills to be developed to improve the efficiency and effectiveness of environmental business activities in order to be able to succeed in the future.

\section{Acknowledgements}

The paper is written based on research within project "Logistics management of defective products in Polish manufacturing enterprises," financed by the National Centre of Science with decision number DEC2012/07/D/HS4/02071.

\section{Conflict of Interest}

The author declares no conflict of interest.

\section{References}

1. STREZOV V., EVANS A., EVANS T.J. Assessment of the economic, social and environmental dimensions of the indicators for sustainable development. Sustainable Development, 25 (3), 242, 2017.

2. BAJDOR P. Sustainable Development: Historical Background, Strategies, Dimensions and Future Challenges. Valahia University Press: Targoviste, Romania, 2017.

3. CLARK W.C., VAN KERKHOFF L., LEBEL L., GALLOPIN G.C. Crafting usable knowledge for sustainable development. Proceedings of the National Academy of Sciences, 113 (17), 4570, 2016.

4. KEEYS L.A., HUEMANN M. Project benefits co-creation: Shaping sustainable development benefits. International Journal of Project Management, 35 (6), 1196, 2017.

5. SIVA V., GREMYR I., BERGQUIST B., GARVARE R., ZOBEL T., ISAKSSON R. The support of Quality Management to sustainable development: A literature review. Journal of Cleaner Production, 138, 148, 2016.

6. NITKIEWICZ T. Product life cycle assessment in decision processes of manufacturing enterprises. Wydawnictwo Politechniki Częstochowskiej: Częstochowa, Poland, 2013 [In Polish].

7. ŚLUSARCZYK B., BARYŃ M., KOT S. Tire industry products as an alternative fuel. Polish Journal of Environmental Studies, 25 (3), 1263, 2016.

8. ILGIN M.A., GUPTA S.M. Environmentally conscious manufacturing and product recovery (ECMPRO): A review of the state of the art. Journal of Environmental Management, 91, 563, 2010.

9. VAN DER RYN S., COWAN S. Ecological design, $10^{\text {th }}$ ed. Island Press: Washington, United States, 2013.
10. SHU-YANG F., FREEDMAN B., COTE R. Principles and practice of ecological design. Environmental Reviews, 12 (2), 97, 2004.

11. YEANG K. Ecodesign: A manual for ecological design. Wiley-Academy: London, Great Britain, 2006.

12. VAN HEMEL C., CRAMER J. Barriers and stimuli for ecodesign in SMEs. Journal of cleaner production, 10 (5), 439, 2002.

13. KULCZYCYKA J., LELEK Ł., LEWANDOWSKA A., ZAREBSKA J. Life Cycle Assessment of Municipal Solid Waste Management - Comparison of Results Using Different LCA Models. Polish Journal of Environmental Studies, 24 (1), 125, 2015.

14. KNIGHT P., JENKINS J.O. Adopting and applying ecodesign techniques: a practitioners perspective. Journal of Cleaner Production, 17 (5), 549, 2009.

15. GURAUSKIENĖ I., VARŽINSKAS V. Eco-design Methodology for Electrical and Electronic Equipment Industry. Environmental Research, Engineering \& Management, 37 (3), 43, 2006.

16. RAMANI K., RAMANUJAN D., BERNSTEIN W.Z., ZHAO F., SUTHERLAND J., HANDWERKER C., THURSTON D. Integrated sustainable life cycle design: a review. Journal of Mechanical Design, 132 (9), 091004, 2010.

17. AIT-KADI D., CHOUINARD M., MARCOTTE S., RIOPEL D. Sustainable reverse logistics network. Engineering and Management. John Wiley \& Sons: London, Great Britain, 2012.

18. BYGGETH S., HOCHSCHORNER E. Handling trade-offs in ecodesign tools for sustainable product development and procurement. Journal of Cleaner Production, 14 (15-16), 1420, 2006.

19. DZIKUĆ M., PIWOWAR A. Life Cycle Assessment as an Eco-Management Tool within the Power Industry. Polish Journal of Environmental Studies, 24 (6), 2381, 2015.

20. KHATAMI M., MAHOOTCHI M., FARAHANI R.Z. Benders' decomposition for concurrent redesign of forward and closed-loop supply chain network with demand and return uncertainties. Transportation Research Part E: Logistics and Transportation Review, 79, 1, 2015.

21. SARKIS J. Greener Manufacturing and Operations. From Design to Delivery and Back. Greenleaf Publishing: Sheffield, Great Britain, 2001.

22. DAS K., POSINASETTI N.R. Addressing environmental concerns in closed loop supply chain design and planning. International Journal of Production Economics, 163, 34, 2015.

23. GUPTA S.M. Reverse Supply Chains: Issues and Analysis. CRC Press: Boca Raton, United States, 2013.

24. BLUMBERG D. Introduction to Management of Reverse Logistics and Closed Loop Supply Chain Processes. CRC Press: Florida, United States, 2005.

25. INDERFURTH K., TEUNTER R.H. Production planning and control of closed-loop supply chains. In Business Aspects of Closed Loop Supply Chains, V.D.R. Guide, C. Corbett, R. Dekker, van Wassenhove L.N., Eds., Carnegie Mellon University Press: Pittsburgh, United States, 2, 2002.

26. KOPPIUS O., ÖZDEMIR A.Ö., LAAN E.V.D. Business value from closed-loop supply chains. International Journal of Supply Chain Management, 3 (4), 107, 2015.

27. REZAPOUR S., FARAHANI R.Z., FAHIMNIA B., GOVINDAN K., MANSOURI Y. Competitive closedloop supply chain network design with price-dependent demands. Journal of Cleaner Production, 93, 251, 2015. 
28. CECED Polska. Production of household appliance products in Poland in 2017. Report. Warszawa, Poland, 2018 [In Polish].

29. CECED Polska, Sell of household appliance products in Europe. Report. Warszawa, Poland, 2018 [In Polish].

30. STAROSTKA-PATYK M. Reverse logistics of defective products in management of manufacturing enterprises. Wydawnictwo Naukowe Sophia: Katowice, Poland, 2017.

31. KUMAR V.N.S.A., KUMAR V., BRADY M., GARZAREYES J.A., SIMPSON M. Resolving forward-reverse logistics multi-period model: An artificial immune system algorithm based approach. International Journal of Production Economics, 183 (B), 458, 2017.

32. ROGERS D.S., TIBBEN-LEMBKE R. Going Backwards: Reverse Logistics Trends and Practices. Reverse Logistics Executive Council: Reno, United States, 1999.
33. Report on the functioning of waste electrical and electronic equipment management system in 2016. Główny Inspektorat Ochrony Środowiska: Warszawa, Poland, 2017 [In Polish].

34. SZKUTNIK J. Sustainable in Logistic Distribution of Electrical Energy. In The Role of Business in Achieving Sustainability. Implication for Industry; V. Modrak, B. Ślusarczyk, Eds.; Technical University of Kosice: Presov, Slovakia, 2, 110, 2010.

35. PREISNER L., PINDÓR T. Environmental audits as instruments supporting the environmental management system. Logistyka Odzysku, 2 (11), 12, 2014 [In Polish].

36. NOWAKOWSKA-GRUNT J., KABUS J. Factors of production and economic conditions. Wydawnictwo Naukowe Sophia: Katowice, Poland, 2017 [In Polish]. 